\title{
Correction to: Multi-template matching: a versatile tool for object-localization in microscopy images
}

Laurent S. V. Thomas ${ }^{1,2^{*}}$ (D) and Jochen Gehrig ${ }^{1 *}$

The original article can be found online at https://doi. org/10.1186/s12859-0203363-7.

*Correspondence: I.thomas@acquifer.de; j.gehrig@acquifer.de 1 Acquifer Is a Division of Ditabis, Digital Biomedical Imaging Systems AG,

Pforzheim, Germany Full list of author information is available at the end of the article

\section{Correction to: BMC Bioinformatics (2020) 21:44 https://doi.org/10.1186/s12859-020-3363-7}

Following the publication of the original article [1], the authors would like to update Additional file 3 in the supplementary information. The broken link and file have been corrected and updated.

The original article [1] has been corrected.

\section{Supplementary Information}

The online version contains supplementary material available at https://doi.org/10.1186/s12859-021-04524-7.

Additional file 3: Macro. 2step-TemplateMatching.ijm, available on the GitHub repository at https://github.com/ multi-template-matching/MultiTemplateMatching-Fij/blob/master/Fiji.app/scripts/Plugins/Multi-Template-Match ing/2step-TemplateMatching.ijm. See Supplementary Material.pdf and Supplementary Figures.pdf for further information.

Author details

${ }^{1}$ Acquifer Is a Division of Ditabis, Digital Biomedical Imaging Systems AG, Pforzheim, Germany. ${ }^{2}$ Centre of Paediatrics and Adolescent Medicine, University Hospital Heidelberg, Heidelberg, Germany.

Published online: 04 January 2022

Reference

1. Thomas LSV, Gehrig J. Multi-template matching: a versatile tool for object-localization in microscopy images. BMC Bioinform. 2020:21:44. https://doi.org/10.1186/s12859-020-3363-7.

Publisher's Note

Springer Nature remains neutral with regard to jurisdictional claims in published maps and institutional affiliations.

(c) The Author(s) 2021. Open Access This article is licensed under a Creative Commons Attribution 4.0 International License, which permits use, sharing, adaptation, distribution and reproduction in any medium or format, as long as you give appropriate credit to the original author(s) and the source, provide a link to the Creative Commons licence, and indicate if changes were made. The images or other third party material in this article are included in the article's Creative Commons licence, unless indicated otherwise in a credit line to the material. If material is not included in the article's Creative Commons licence and your intended use is not permitted by statutory regulation or exceeds the permitted use, you will need to obtain permission directly from the copyright holder. To view a copy of this licence, visit http:// creativecommons.org/licenses/by/4.0/. The Creative Commons Public Domain Dedication waiver (http://creativecommons.org/publi cdomain/zero/1.0/) applies to the data made available in this article, unless otherwise stated in a credit line to the data. 